\title{
The Digital Technology and the Threat of Downsizing into Indonesia's Banking Industry Performance
}

\author{
Florentina K. Tehubijuluw
}

\begin{abstract}
Downsizing refers to the permanent reduction of a company's workforce and is generally associated with corporate reorganization in the response of the dynamic environment. In this era digital economy, the speed, flexibility and innovation becomes more important. As more and more manual financial transactions become automated, the size of the workforce reduced. The banking industries apply the computing system to business processes to increase efficiency, reduce process errors, enhance productivity and delight the customers. This study contributes to our understanding that even the digital technology will reduce the number of employees in the banking industry, but the customers still need some close relationships and interactions in doing their financial transaction. The bank's performance is mostly influenced by the bank image and the ability to create edge value to the customers.
\end{abstract}

Index Terms-Banking industry, banking performance, digital technology, downsizing strategy, Indonesia.

\section{INTRODUCTION}

Digital technology has developed rapidly in almost all around the world. The Encarta Dictionary defined digital economic as "Business transactions on the Internet: the marketplace that exists on the Internet". Digital technologies such as internet, mobile phones, and all the other tools to collect, store, analyze, and share information digitally - have spread quickly. More households in developing countries own a mobile phone than have access to electricity or clean water, and nearly 70 percent of the bottom fifth of the population in developing countries own a mobile phone. The number of internet users has more than tripled in a decade-from 1 billion in 2005 to an estimated 3.2 billion at the end of 2015 . The digital technologies also have a big impact to change the business activities and economics opportunities. Some advantages of these digital technologies include the easiness to start new business, enlarging the potential market, simplifying the payment system and speedy distribution from all over the world.

The number of active Internet users in Indonesia reached 78 million users of which $7 \%$ are doing transactions over the internet. From the total population of 255.55 million only $28 \%$ of the people are active internet users and social media accounts. Interestingly, $121 \%$ of the Indonesian people have mobile connections with $24 \%$ of them are active mobile social accounts. The higher number of mobile connections compares with the total population shows the possibility of every people

Manuscript received January 22, 2017; revised March 5, 2017.

Florentina K. Tehubijuluw is the lecturer of Matana University, ARA Center, Matana University Building, Gading Serpong, Tangerang, Indonesia (e-mail: florentina@matanauniversity.ac.id). in Indonesia has more than one mobile phone.

Indonesia government under the leadership of President Joko Widodo also has commitment to develop the infrastructure to support the digital economy by launching "The Palapa Ring Project". This project is the development of national infrastructure of fiber optic across the country, which will cover of 34 provinces and 440 cities, with the total length of sea cable $35.280 \mathrm{~km}$ and land cable of $21.807 \mathrm{~km}$.

In the digital economy, information and business environment transaction flows have evolved from physical to virtual. The banking process are now rapidly changing from physical cash, checks, using teller in the bank's branches to electronic data interchange (EDI), electronic funds transfer (EFT), branchless banking system, cashless system using debit or credit cards, automated teller machines (ATM) and internet banking. The components of economic transactions are now representing by the data flowing across global networks. Companies must fundamentally rethink their core business models to prepare for the digital economy by adjusting the organizational strategy, manpower planning and technology infrastructure [1]. Forward-thinking and competitive organizations such as Federal Express, Toyota and Wal-Mart consider the information technology as a weapon to integrate the business units and dissolve barriers to gain more competitive advantage [2].

Changes in the external environment especially the rapid growth of the digital technology drive the need for organizational change and often result in downsizing [3]. Downsizing which is a proactive strategy defined as a process which results in layoffs and the streaming of functions as well as the redesigning of systems. It refers to a process where a company or a firm simply reduces its workforce in order to cut the operating costs and improve efficiency and thus economic growth. Downsizing has become a legitimate option for business growth strategies especially after the 1980s [4]. Organizational downsizing has become a common practice aimed to improve organizational outcomes. It is referred to as "the planned elimination of positions or jobs" [5] and may incorporate workforce reduction, work redesign, and systematic change [6].

The economic slowdown in Indonesia is also give some affect in the banking industry. Some banks are experienced in the increasing rate of Non-Performing Loan (NPL) from $2.16 \%$ in 2014 into $2.96 \%$ in the beginning of 2016, the failure of credit payment from the customers and the decreasing of net interest revenue [7]. On the other side, the operational expenses ratios (especially in employee compensation packages and branch operational cost) into the operational revenues are tremendously growing. In order to survive, some banks are trying to reduce unnecessary cost by 
closing some branches, focusing more on profitable businesses, reducing the number of employees and investing more on the technology infrastructure. Digital transformation in the banking industry in Indonesia is important to increase the quality services to the customers. With the branchless banking, the bank can offer some innovative and electronic financial transaction done by the customers themselves. The delivery channel can be more simplified and can be followed by limiting the number of employees.

The purpose of this study is to investigate whether the bank investment in the digital technology will replace the employee's role and improve the bank's performance in Indonesia.

\section{LITERATURE REVIEW}

Digital economic was defined as the virtual arena in which business actually is conducted, value is created and exchanged, transactions occur, and one-to-one relationship mature by using any internet initiative as medium of exchange [8]. The digital economy now permeates countless aspects of the world economy, impacting sectors as varied as banking, retail, energy, transportation, education, publishing, media or health. Information and Communication Technologies (ICTs) are transforming the ways social interactions and personal relationships are conducted, with fixed, mobile and broadcast networks converging, and devices and objects increasingly connected to form the Internet of Things [9]. According to Kumar et al. [10] technology consists of two primary components: 1) a physical component which comprises of items such as products, tooling, equipment, blueprints, techniques, and processes; and 2) the informational component which consists of know-how in management, marketing, production, quality control, reliability, skilled labor and functional areas.

Downsizing is a deliberate organizational decision to reduce the workforce that is intended to improve organizational performance and organizational effectiveness [11]; is typically aimed at improving efficiency and is the result of a combination of organizational factors and environment [12]. Downsizing is one of the modern key concepts of manpower planning. It is generally associated with corporate re-organization to create a more efficient and leaner company. Downsizing is the systematic reduction of a workforce through an internationally instituted set of activities by which organizations aim to improve efficiency and performance [13], [5]. De Meuse [14] defined downsizing as "a large permanent, reactive layoffs, a streamlining of functions, a redesign of systems, a redefinition of policies aimed at cutting costs and a proactive strategy." Bank and Tustin [15] posited that downsizing is one tactic within a corporate strategy for shifting the organizational structure from what it is now to what it has to be in order to sustain competitive edge and satisfy customer's needs. The reason advanced for downsizing is also to improve service delivery and promote good governance. Some of benefits of downsizing include faster decision making, greater flexibility or improvement in quality and increase efficiency and productivity [3], [12]. Downsizing is also an intentional, proactive, and often reactive managerial strategy aimed at generating sustainable fit and adequate responses to external-environmental turbulence and uncertainty [16].

A wide variety of organizational measures have been used to assess the performance of the organization, such as: financial performance, increase customer satisfaction and positive brand image [13]. In turn, higher customer satisfaction and loyalty leads to improve revenue, profitability, and cash flows [17]. Increased cash flows could come from the acquisition of additional customers. The interest in measuring customer satisfaction is reflected in its ability to help build up customer loyalty [18]; enhance favorable word of mouth [19], lead to repeat purchases [20] and improve the company's market share and profitability [21]. A key motivation for the growing emphasis on customer satisfaction is that higher customer satisfaction can lead to a stronger competitive position resulting in higher market share and profit [20]; reduce price elasticity, lower business cost, reduce failure cost and reduce the cost of attracting new customers. Customer satisfaction is also generally assumed to be a significant determinant of repeat sales, positive word of mouth and customer loyalty. Satisfied customers return and buy more and they tell other people about their experiences and also strengthening the company brand image [20].

Based on the literature review above, the researcher proposed the theoretical framework as follows:

$\frac{\text { Digital Technology }}{\mathrm{H} 3} \underset{\text { Downsizing Strategy }}{\mathrm{H}} \stackrel{\mathrm{H} 2}{\mathrm{H}_{\text {Banking Performance }}}$

Fig. 1. The Theoretical framework.

From the framework above, the researcher proposed some hypotheses as follows:

$\mathrm{H}_{1}$ : There's an effect between the digital technology and the downsizing strategy

$\mathrm{H}_{2}$ : There's a positive effect between the downsizing strategy and the banking performance

$\mathrm{H}_{3}$ : There's a significant effect between the digital technology and the banking performance

\section{RESEARCH METHODOLOGY}

The empirical part is based on quantitative survey results from the theoretical framework. The digital economic data will be analyzed using the published of Indonesia government report including the strategic development of telecommunication infrastructure and also stated by the Economist Intelligence Unit (EIU) [22], which include: the ICT infrastructure $\left(\mathrm{X}_{1}\right)$, the business environment $\left(\mathrm{X}_{2}\right)$, the social and cultural environment $\left(\mathrm{X}_{3}\right)$ and consumer and business adoption $\left(\mathrm{X}_{4}\right)$. The downsizing strategy $\left(\mathrm{Y}_{1}\right)$ was characterized by the reducing the number of current employees [14] and for the banking performance will be measured by the rate of customer satisfaction $\left(\mathrm{Y}_{2}\right)$, the bank image $\left(\mathrm{Y}_{3}\right)$, and the bank's financial performances $\left(\mathrm{Y}_{4}\right)$ [17].

The research questionnaires in this study consisted two parts. The first part was drawn for collecting demographic information profile of the respondents regarding their age, gender, level of education, job position and work tenure. The second part of questionnaire represented the main research 
questions is taken from the previous study done by some researchers. Each question will be measured base on Likert $5^{\text {th }}$ option spectrum coded from: Scale $1=$ Very Disagree, Scale $2=$ Disagree, Scale $3=$ Doubtful, Scale $4=$ Agree and Scale 5 = Very Agree.

The research design in this study is hypotheses testing using cross-sectional time dimension; field study research, causality with individual as unit analysis. This research will discuss the sampling technique, instrumentation and the data screening before proceeding to the Structural Equation Models (SEM) technique in testing the hypothesized model and invariance analysis. The samples for this research are customers from four biggest banks in Indonesia based on the market capitalization in the Indonesia Stock Exchange, which include: one private bank (PT BCA, Tbk) and three state-owned banks (PT Bank Mandiri, Tbk, PT Bank BNI, Tbk and PT Bank BRI, Tbk).

The researcher decided to distribute 400 questionnaires, in which each bank will be represented by 100 respondents.

Validity construct is used to determine the validity by correlating among scores for each item in form of questions or total score using Pearson correlation. Based on validity testing in the questionnaire for each variable for 50 respondents (pre-test) with critical $t>0.757$ showing that all items have greater correlation value and VALID.

The elements the reliability of the questionnaire evaluated by Cronbach's alpha coefficient and admissible is all values yielded alpha coefficient exceeded the values of 0.50 suggested by Nunnaly [23]. The pre-test showed that the alpha reliability value is greater than 0.758 and VALID. Hair et.al [24] said that if the overall model has been fit, measurement of every construct can be done for un-dimensional and reliability. In this study, Confirmatory Factor Analysis (CFA) is used because the research model and latent variables have been determined before.

Evaluation on analysis of structural model includes examination of correlation of latent variables in this research. If significance degree reaches alpha $=0.05$ and $t$-value $>=$ 1.96 , then significance of every coefficient that represents causal relation that is hypothesized can be tested systematically. The Goodness-of Fit (GOF) indicates how well the specified model reproduces the observed variance matrix among the indicator items and for this research the result showed that all GOF is more than $\geq 0.90$. Since the observed and estimated covariance matrices would be the same, it can be stated that this research theory were perfect.

\section{RESULTS AND DisCUSSIONS}

All primary data will be analyzed using the statistical package SPSS for Windows. The study will use a structural equation method to identify the strength, direction and impact of each indicator.

From data analysis, this study able to create a Structural Equation Model as follows:

$$
\begin{aligned}
& \mathrm{OP}=0.21 * \mathrm{DT}+0.04 * \mathrm{DS}+0.47 * \mathrm{BF}, \text { Errorvar. }=0.42, R^{2}=0.58 \\
& \begin{array}{llll}
(0.043) & (0.040) & (0.053) & 0.069
\end{array} \\
& \begin{array}{llll}
5.87 & 2.06 & 7.97 & 10.03
\end{array}
\end{aligned}
$$

(Source: LISREL OUTPUT 8.70)

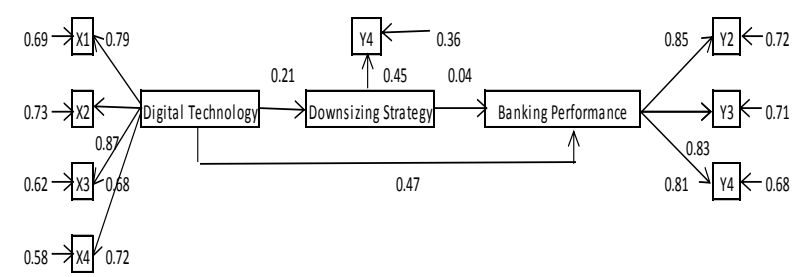

Fig. 2. The Structural diagram (Standardize).

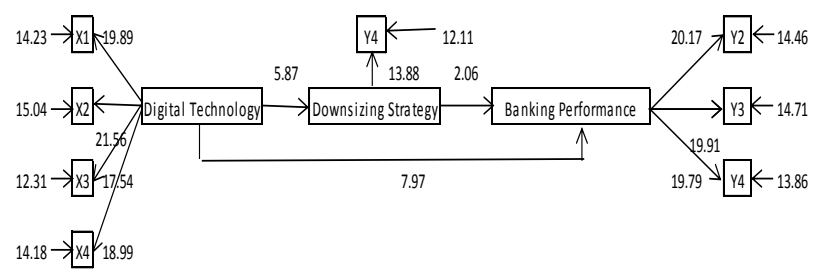

Fig. 3. The Structural diagram (T-Value).

The result of all hypothetical tests indicates that all hypotheses tested on all respondents are supported by data.

Hypothesis 1: There is a positive effect between digital technology and downsizing strategy, because $t$-value $\geq 2$ (5.87), with the rate of effect 0.21 . The business environment has the greatest value within the digital technology dimensions. Business environment in Indonesia are growing abundantly following the economic growth and government commitment to develop the ICT infrastructure [25]. In emerging economies around the world, the interest in digital technology is currently higher than ever amid burgeoning youth populations and a desire to move up value chains. They are more familiar with gadget or social media, like to spend hourly in the internet and do more online shopping [26].

Hypothesis 2: There is an effect between the downsizing strategy and banking performance, with the $\boldsymbol{t}$-value $\geq \mathbf{2}(\mathbf{2 . 0 6})$, with the rate of effect 0.04 . This result is supported the previous research done by Kozlowski, et.al. [11] who stated that the downsizing strategy is one alternative way to reduce the number of employee to increase organization efficiency.

Hypothesis 3: There is a greatest effect between the digital technology and the banking performance with the $\boldsymbol{t}$-value $\geq 2$ (7.97), with the rate of effect 0.053 . Digital technology is proven to improve banking performance. Some banks are heavily invested to develop the ICT infrastructure run the business efficiently. The successful exploitation of new ideas is crucial to a business being able to improve its processes, bring new and improved products and services to market, increase its efficiency and, profitability. Understanding the consumer and business process will assist the bank to create more innovative strategies in capturing the market [27]. Hussain, MF, et al. [26] also stated that technology provides the solution of the problems that is generated by innovation. Technology will simplify the business transaction process, make customers feel comfortable and safe time in doing their financial transaction. The ability of the banks to create a good image in customer's mind will make the bank become a priority choice for the customers in doing their financial transaction.

Data from the survey also showed that even the majority of respondents had knowledge of digital banking system (98\%), only $17 \%$ of them using the e-channel in doing their financial 
transactions. The respondents still afraid and unsure about the safety of doing the financial transaction using electronic channel. From the demographic data, all respondents (both male and female) knew well about the bank products and services. The respondents with the range age of 21-30 years had higher knowledge about the e-banking products compare with the older age 41-50 years. Meanwhile, the respondents with age of 51-55 years had the lowest knowledge of the electronic banking products and services. Respondents with higher educational level (university graduates) had better understanding of e-banking services compare with the respondents at the lower educational level (high-school graduates). Respondents who were coming from the A segment class also had better familiarity with the e-banking services compare with other segment class level (lowest are coming from the $\mathrm{C}+$ segment). The respondents associate the bank with the good technology infrastructure with the number of automated teller machines provided by the bank. Majority respondents are using the e-channel for bills payment (85\%), online shopping (76\%), online transfer $(65 \%)$ and top-up for e-money $(53 \%)$.

\section{MANAGERIAL IMPLICATIONS}

The results of this study also have original implications for banking industries that the digital technologies have the most significant effects into the banking performances in Indonesia. The safety business environment which is supported with a good ICT infrastructure will encourage the customer to do online financial transactions. The study also showed that the social-cultural environments had lowest effect in forming the entrepreneurship characteristic in Indonesia. The result also confirms that social and cultural environment will improve the growing of digital technology in Indonesia. This finding is in the same conjunction with Hofstede's cultural dimensions in which positioning Indonesia as a collectivism country [28]. Collectivism meaning that there's a long-term commitment to the families, social groups and extended relationship. The banking customers will more easily influenced by their friends and peer-groups in doing their financial transaction. Most of them are gadget, media social and internet users friendly and also doing the online business transaction frequently. They request more on high-speed internet capacity and free-wifi access anywhere. Therefore, there's urgency for the Indonesian government to develop the technology infrastructure and increase the connectivity capacity. With modern technology infrastructure and supported with the more speedy bandwidth, hopefully it will encourage more customer are doing their electronic financial transaction. The banking industries will face some challenges in which they have to spend more money for the technology investments and in the same time the slowdown of the national economic in the upcoming year. And also there's another issue regarding the implementation of the government regulation about the electronic business transactions.

Digital transformation is not simply just automation of existing business process but increases the productivity of the people to grow sales and profits. The organization must empower the knowledge worker to be more creative in creating the value for all the customers. Organizations must consider all some facts and works within their strategic framework when deciding to utilize the information technology, include the employee support, adequate infrastructure, and also cost. This advancing technology will results in the displacement of the employee, which can be also make some disruptions in the productivity, efficiency, loss of morale, lack of innovation and competitiveness [5], [12], [13]. Therefore, there's some urgency to make the smooth transition from the existing into new business process.

Even the digital technology will replace the human roles in doing the financial transaction works, some customers still needs their appearance especially for huge transactions. They are still afraid about the fraud and safety aspects in doing electronic banking transactions. The older age respondents are also more comfortable doing the financial transaction with the bank's employee assistances. New technology has also forced the corporate users and all the customers to become more computer literate. The organization must assist all of them in employing the simple and user-friendly technology to do their financial transactions. The bank should ensure the safety and convenience of using the e-banking system by giving appropriate knowledge of the product services.

One consideration for the customer in choosing the bank is the bank image and reputation. Bank image and reputation is formed by the transparency and the good services delivered by the employees. Therefore, there is also an urgency to give more attention to develop the employee skill and knowledge in serving the customers. The companies must regularly give appropriate training and establish a corporate value that are put the customers as the top priority.

\section{SugGeSted FuRTHER RESEARCH}

First, it is very important for further studies to consider other variables that can influence the respondents in choosing their banks, such as: the bank reputation, the convenience and bank services. Second, the further researches can also enrich their studies by linking the demographic data of the respondents directly to the downsizing strategy and the banking performance.

\section{REFERENCES}

[1] S. Jack and C. Ball, "Reflects innovation, transformation in digital economy," Metal Producing, vol. 38, no. 7, p. E4, 2000.

[2] J. Callon, Competitive Advantage: Through Information Technology. McGraw-Hill, New York, NY, 1996.

[3] R. M. Tomasko, Downsizing: Reshaping the Organization for the Future, New York, Amacom, 1990.

[4] Clement and Ejefobihi, "Downsizing as a strategic tool for corporate performance and economic growth of Nigeria: An exploratory analysis," IJCRR Section Healthcare, vol. 7, issue 11, pp. 33-38, 2015.

[5] W. Cascio, "Downsizing: What do we know? What have we learned," Academy of Management Executive, vol. 7, no.1, pp. 95-104, 1993.

[6] R. D. Iverson and J. A. Pullman, "Determinants of voluntary turnover and layoffs in an environment of repeated downsizing following a merger: An event history analysis," Journal of Management, vol. 26, pp. 977-1003, 2000.

[7] E. Supriyanto, "Kinerja perbankan nasional di tengah krisis ekonomi di Indonesia,” Infobank Magazine, vol. XXXVIII, no. 446, pp 23-25, 2016.

[8] A. Hartman, G. S. John, and J. Kador. Net Ready: Strategies for Success in the Economy, San Fransisco: McGraw-Hill, 2000. 
[9] OECD, Digital Economy Outlook 2015, OECD Publishing, Paris, 2015.

[10] V. Kumar, U. Kumar, and A. Persaud, "Building technological capability through importing technology: The case of Indonesian manufacturing industry," Journal of Technology Transfer, vol. 24, pp. 81-96, 1999

[11] S. W. J. Kozlowski et al., "Organizational downsizing: Strategies, interventions and research implications," International Review of Industrial and Organizational Psychology. New York: John Wiley and Sons, pp. 263-332, 1993.

[12] S. J. Freeman and K. S. Cameron, "Organizational downsizing: A convergence and reorientation framework. Organization Science, 4(1), pp. 10-29. doi: 10.2307/2635038, 1993.

[13] Cameron, and S. Kim, Investigating Organizational Downsizing. Human Resource Management Executive, vol. 7, no.1, pp. 95-104, 1994.

[14] De Meuse, K.P; P.A Vanderheiden, and J.J. Bergmann, Announced Layoff, 1994.

[15] D.C Bank and Justin, Strategic Downsizing. Management Decision, vol. 33 no. 8 , pp. 36-45, 1995.

[16] W. Weitzel and E. Jonsson, Decline in Organizations: A Literature Integration and Extension. Administrative Science Quarterly, vol. 34 pp. 91-109, 1989.

[17] J. L. Heskett, W. E. Sasser, and L. A. Schlesinger, The Service Profit Chain: How Leading Companies Link Profit and Growth to Loyalty, Satisfaction, and Value, Free Press: New York, NY, 1994.

[18] Cronin and taylor measuring service quality: A reexamination and extension, Journal of Marketing, vol. 56, pp. 55-68, 1992.

[19] D. Halstead et al., "The effects of satisfaction and complaining behavior on consumer repurchase behavior," Journal of Satisfaction, Dissatisfaction and Complaining Behavior, vol. 5, pp. 1-11, 1992.

[20] C. Fornell, "A national customer satisfaction barometer: The Swedish experience," Journal of Marketing, vol. 56, pp. 6-21, 1992.

[21] Oh and Parks, "Customer satisfaction and service quality: A critical review of the literature and research implications for the hospitality industry," Hospitality Research Journal, vol. 20, no. 3, pp. 35-64, 1997.
[22] Economist Intelligence Unit, Digital Economy Rankings in Year 2010, 2010.

[23] J. Nunnaly, Psychometric Theory, New York: McGraw-Hill, 1978.

[24] Hair et al., Multivariate Data Analysis. Pearson Education: New Jersey, 2010.

[25] Cordova et al., Creating the Environment for Entrepreneurial Success, Center for International Private Enterprise, 2015.

[26] M. F. Hussain et al., "Impact of innovation, technology and economic growth in entrepreneurship," American International Journal of Contemporary Research, 2011.

[27] World Bank, World Development Report 2016: Digital Dividends, Washington, DC.: World Bank, 2016.

[28] G. Hofstede, Culture's Consequences: Comparing Values, Behaviors, Institutions and Organizations across Nations, 2nd Ed. Thousand Oaks, CA: SAGE Publications, 2001.

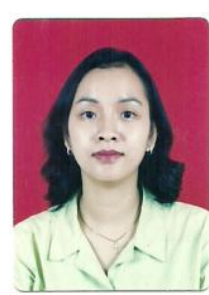

Florentina K. Tehubijuluw was born in Jakarta on April 14, 1974. She earned her bachelor degree in business administration within four years by Cum-Laude from University of Indonesia (Jakarta, Indonesia) in 1996. Her master in business management degree was earned from Asian Institute of Management, Manila, Philippines in 1999. Her doctoral economics was earned within four years also Indonesia in 2014. by Cum-Laude from Trisakti University, Jakarta,

Currently she has a managerial position as deputy rector in financial and administration program at Matana University, and in the same time, she is also as lecturer specialized in management strategy and marketing courses, for bachelor and master degree. She is actively involved in the religious activities and holds some strategic position in religious institution especially related with the human capital development. She is also actively as a public speaker and lecturer in some universities and private companies in Indonesia relates with the economic and management studies.

Her papers were published in some national and international journals and her books were published national and international wide. 